\title{
Szkice
}

\section{Imię jako pępek snu, czyli jak odzyskać rzeczy, których nigdy nie mieliśmy}

Adam Lipszyc

TEKSTY DRUGIE 2016, NR 5, S. 19-39

DOI: $10.18318 /$ td.2016.5.2

\section{C} hoć nie ulega wątpliwości, że Objaśnianie marzeń sennych to dzieło mistrzowskie i niezwykle skomplikowane na poziomie wywodów szczegółowych, zrazu trudno oprzeć się wrażeniu, że procedura hermeneutyczna, której zasady kreśli Freud w swoim opus magnum, jest wręcz rozczarowująco prosta. Rzućmy bowiem okiem na to, co dobrze znane. Freud wprowadza rozróżnienie między utajoną a jawną treścią snu. Ta ostatnia powstaje z tej pierwszej dzięki zniekształcającej pracy marzenia sennego, wymuszonej przez cenzurę psychiczną. Tak więc dzięki zasadniczym mechanizmom pracy marzenia sennego - tj. dzięki kondensacji, przemieszczeniu, symbolizacji i opracowaniu wtórnemu - utajona narracja skoncentrowana wokół spełnienia nieświadomego pragnienia, zakorzenionego zazwyczaj w naszym wczesnym dzieciństwie, przeobraża się w intrygujący, enigmatyczny, lecz dopuszczalny przez instancje cenzorskie jawny tekst marzenia sennego. Skoro tak, to procedura zwana die Traumdeutung wydaje się po prostu inwersją zniekształcenia, które wytwarza sen. Jest to proces przekładu, który pozwala rozwiązać zagadkę obrazkową, rebus marzenia
Adam Lipszyc eseista i tłumacz, pracuje w Instytucie Filozofii i Socjologii PAN, uczy w Szkole Nauk Społecznych, w Collegium Civitas oraz na Uniwersytecie Muri im. Franza Kafki. Zajmuje się pograniczami filozofii, teologii i literatury. Laureat nagrody "Literatury na Świecie" im. Andrzeja Siemka, nagrody Allianz Kulturstiftung i Nagrody Literackiej Gdynia. Kontakt: adamlipszyc@gmail. com 
sennego, zrekonstruować pierwotny tekst utajonej treści snu i otworzyć królewską drogę do nieświadomego pragnienia'.

Dla każdego czytelnika Objaśniania marzeń sennych jasne jest wszelako, że ta procedura bywa dość często i na wiele sposobów kwestionowana, relatywizowana i podważana w drobiazgowych analizach wypełniających arcybogatą książkę Freuda. W szczególności twierdzenie, które wydaje się najważniejszą, a przynajmniej najbardziej wyeksponowaną tezą książki - myśl, że każde marzenie senne przedstawia pewne nieświadome pragnienie jako spełnione - wydaje się nie do uzgodnienia z przynajmniej kilkoma snami, które Freud przytacza w charakterze przykładów, i rzeczywiście - jak wiadomo - ten aspekt doktryny ojciec psychoanalizy zmodyfikował na dalszym etapie rozwoju swojej myśli, choć jedynie po części i z wyraźnymi oporami². Ciekawsze wydają się jednak niejakie wahania Freuda co do rozumienia samej procedury hermeneutycznej, stanowiącej metodologiczny rdzeń jego dzieła. Przede wszystkim warto przypomnieć, że w pewnym przypisie dodanym w roku 1925 Freud ostrzegał swoich czytelników i uczniów przed pomyłką, za którą sam mógł być po trosze odpowiedzialny. Błędem jest sądzić, pisał tutaj mianowicie, że „istotą” marzenia sennego jest jego treść utajona; w rzeczywistości istoty tej należy szukać w „formie” snu, o tej zaś stanowi zniekształcająca praca marzenia sennego ${ }^{3}$. Rzecz jasna, sam ów przypis nie musi koniecznie kwestionować nakreślonego powyżej odczytania Freudowskiej procedury interpretacji snów. Jeśli ktoś chce się dowiedzieć, czym jest list, należy mu oczywiście wyjaśnić wszystkie administracyjne, ekonomiczne, społeczne i językowe mechanizmy i praktyki tworzące razem instytucję zwaną pocztą, one to bowiem stanowią o „formie” listu, a zatem - jeśli wola - o jego „istocie” jako pewnego specyficznego aktu językowego; bez sprzeczności można jednak nadal utrzymywać, że wszystko to nie podważa tezy, zgodnie z którą procedura „objaśniania listów” musi przecież zmierzać do poprawnego odczytania ich - czasem zaszyfrowanej, tj. zniekształconej treści. Freud mógł się obawiać, że nadmierny nacisk na treść przekazu, tj. na

1 Jeśli chodzi o szczególnie klarowne (i słynne) sformułowanie tych ogólnych zasad, zob. S. Freud Objaśnianie marzeń sennych, przeł. R. Reszke, KR, Warszawa 1996, zwłaszcza s. 99 oraz s. 243-244.

2 Zob. S. Freud Wykładyze wstępu do psychoanalizy. Nowy cykl, przeł. P. Dybel, KR, Warszawa 1995, s. $34-35$.

3 S. Freud Objaśnianie marzeń sennych, s. 426. Zob. także tegoż Wykłady ze wstępu do psychoanalizy. Nowy cykl, s. 10. 
utajoną treść marzenia sennego, przesłoni wszystkie mechanizmy zniekształcenia, bez których marzenie senne w ogóle nie byłoby marzeniem sennym. W szczególności, można zasadnie dowodzić, że jeśli powodem, dla którego w ogóle uruchamia się praca marzenia sennego, jest cenzura psychiczna, to koncentracja na samych mechanizmach zniekształcenia daje nieoceniony wgląd w strukturę owej wewnętrznej instancji kontroli, którą z czasem Freud począł określać mianem superego.

A przecież można by wskazać całkiem inne intencje skrywające się za Freudowskim ostrzeżeniem - i całkiem odmienne odczytanie owego przypisu. Czytelnik książki Freuda może odnieść wrażenie, że podejmując proces interpretacji, odwracamy zniekształcający proces pracy marzenia sennego, a wówczas odzyskujemy utajoną treść i nic nie zostaje utracone. Dodając po latach ów przypis, Freud starał się być może powiedzieć, że wrażenie to jest mylne i że w wyniku takiej objaśniającej inwersji ulatnia się coś bardzo ważnego. Zaproponowana powyżej rekonstrukcja Freudowskiej procedury hermeneutycznej milcząco zakłada, że utajony, nieświadomy tekst ukryty jest pod lub za tekstem jawnym i świadomym - i że w istocie oba teksty mają podobną naturę. A przecież przeważająca część tego, co Freud ma do powiedzenia o nieświadomości, wskazuje, że błędem jest uważać ją za nieświadomą świadomość. Tak więc w owym przypisie z roku 1925 Freud - po trosze wbrew sobie - próbował bodaj powiedzieć, że istnieje coś, co może ukazać się jedynie w zniekształceniu, jedynie na powierzchni jawnej treści sennej, i że właśnie owo „coś” jest istotą marzenia sennego: nie jako istota mechanizmu, który marzenie wytwarza, lecz jako prawdziwie nieświadoma „rzecz”, ku której powinna kierować się procedura zwana die Traumdeutung.

Wydaje się, że Freud nigdy otwarcie nie postawił tej tezy, musieli więc to za niego zrobić lacaniści ${ }^{4}$. Już w Objaśnianiu marzeń sennych przyznawał jednak, że wyniki rekonstruowanej powyżej procedury muszą pozostać fragmentaryczne. Albowiem ta dobrze dziś znana, z pozoru uniwersalna i wszechmocna procedura zawsze musi roztrzaskać się o to, co nieznane. Jak wiadomo, to, co niewiadome określone zostaje tutaj nieco komicznym mianem „pępka snu”: dokładniej zaś w ten sposób Freud nazywa punkt, w którym marzenie senne styka się z tym, co nieznane. Przeczytajmy ten słynny fragment:

4 A dokładniej Slavoj Žižek, który w tym duchu właśnie analizuje ów przypis Freuda na pierwszych stronach książki o ideologii, stwierdzając błyskotliwie i nader przekonująco, że „jedynym miejscem [pragnienia] jest forma marzenia sennego". Zob. S. Žižek Wzniosły przedmiot ideologii, przeł. ). Bator, P. Dybel, Wydawnictwo UWr, Wrocław 2001, s. 24-28 (cytowane słowa na s. 27). 
Nawet w wypadku najlepiej objaśnionych marzeń często trzeba pozostawić pewne miejsce w mroku, ponieważ w trakcie wykładania zauważa się, że bierze tam początek kłąb myśli sennych (ein Knäuel von Traumgedanken), który opiera się rozwikłaniu, który jednak nie wniósł też żadnego dalszego wkładu do treści sennej. Jest to pępek snu, miejsce, w którym dotyka on tego, co nieznane. W ogólności bowiem myśli senne, na jakie natykamy się w trakcie objaśniania, muszą wszak zawsze pozostać bez zakończenia i zawikłane na podobieństwo sieci wybiegać w świat naszych myśli. Z pewnego gęstszego miejsca w tym splocie wzrasta potem pragnienie senne niczym grzyb ze swojej grzybni. ${ }^{5}$

Warto zwrócić uwagę na osobliwości Freudowskiej retoryki. Godna odnotowania wydaje się przede wszystkim charakterystyczna i dość zabawna okoliczność, że w tym samym fragmencie, w którym ojciec psychoanalizy stawia tę doniosłą tezę, stara się ją zarazem retorycznie osłabić i wyciszyć. Sugeruje mianowicie, że teza ta jest - po pierwsze - oczywista, ponieważ każde marzenie senne musi „wszak” łączyć się z całością naszego życia psychicznego; po drugie - nieszkodliwa, ponieważ choć ów kłąb „opiera się rozwikłaniu”, właśnie dlatego nie wnosi też nic do treści marzenia. Defensywny charakter tego sposobu postawienia sprawy nie ulega wątpliwości. Ratując swoją procedurę przed własną, potężną tezą, Freud próbuje zbagatelizować ów mroczny punkt, na który sam przed chwilą wskazał. Dokładniej rzecz ujmując, próbuje odwrócić naszą uwagę od faktu, że ów tajemniczy splot nie może dopomóc w rekonstrukcji utajonej treści marzenia sennego, ponieważ jego istnienie kwestionuje, a po części rujnuje samą ideę takiej rekonstrukcji. Jeśli bowiem traktujemy poważnie obraz kłębu myśli, który nie poddaje się rozwikłaniu, to nie chodzi przecież o to, że zrekonstruowany tekst będzie fragmentaryczny i postrzępiony na brzegach; jest raczej tak, że ze względu na owo zawrotne zgęszczenie nigdy nie uda się rozprostować nawet najdrobniejszego urywka kartki z tekstem snu. Co gorsza, choć Freud - znów chyba w geście obronnym - pozostawia otwartą kwestię, czy ów pępek należy utożsamiać z owym "gęstszym miejscem", o którym mowa w ostatnim zdaniu fragmentu, takie odczytanie wydaje się oczywiście najbardziej naturalne, wszystko wskazuje więc na to, że pępek marzenia sennego jest po prostu jego punktem centralnym, ponieważ wyznacza właściwe miejsce pragnienia.

5 S. Freud Objaśnianie marzeń sennych, s. 443. Przekład zmodyfikowany. 
Sama metaforyka pępka także zasługuje na komentarz. Wedle słów Freuda ma ona opisywać punkt, w którym marzenie senne „dotyka” tego, co nieznane, do nieznanego się dosiada (aufsitzt). Warto przypomnieć, że figura pępka snu pojawia się po raz pierwszy wiele stron wcześniej, w przypisie komentującym ni mniej, ni więcej tylko modelową analizę snu o zastrzyku Irmy $\mathrm{w}$ istocie więc procedura interpretacyjna zostaje zakwestionowana, zanim na dobre się ją sformułuje. W tym przypisie Freud posługuje się innym czasownikiem, sugerującym ściślejszą więź między snem i tym, co nieodgadnione: zgodnie z tą wcześniejszą formułą „pępek” miałby być czymś, „poprzez” co marzenie senne „łączy się” (zusammenhängt) z nieznanym. W tym sformułowaniu chwiejny charakter metafory pępka ukazuje się aż nadto wyraźnie: czy Freud nie myślał tu raczej o pępowinie? To przecież pępowina łączy coś z czymś (dziecko z matką), pępek zaś jest właśnie blizną po zerwaniu łączności ${ }^{6}$. Metaforyka Freuda chwieje się - chwiejność ta wydaje się jednak nader płodna. Jeśli bowiem - po części na przekór samemu Freudowi - potraktujemy poważnie jego tezę o centralnym charakterze owego enigmatycznego punktu, metaforyka pępka okaże się aż nadto stosowna właśnie dzięki swej niestosowności. Albowiem nieznane, z którym jesteśmy połączeni pępowiną, nie jest już wcale nieznane. Z nieznanym możemy być połączeni tylko poprzez zerwanie, tylko za pośrednictwem blizny - czyli właśnie pępka.

Otóż wydaje się rzeczą całkiem naturalną, by ów pępek utożsamić z tym, co zdefiniowaliśmy powyżej jako istotę marzenia sennego: z ową rzeczą właśnie, która obecna jest jedynie w zniekształconej, jawnej treści snu. Jeśli nie oprzemy się pokusie takiego utożsamienia - ja zaś oprzeć się jej nie potrafię - równie naturalnie będziemy mogli przeformułować procedurę zwaną die Traumdeutung, która wobec centralnego charakteru owego pępka nie może już utrzymać się w postaci zaprezentowanej na początku. Zgodnie z takim przeformułowanym ujęciem, objaśniając sen, będziemy, oczywiście, zwracali uwagę na identyfikowalne przejawy pracy marzenia sennego obecne w jawnym tekście snu, po to by rozerwać nazbyt gładką powierzchnię narracji wytworzonej przez opracowanie wtórne. Wierni Freudowi, zwrócimy więc uwagę na przypadki kondensacji, przemieszczeń i symbolizacji. Ów krytyczny demontaż nie zaowocuje wszakże równie gładkim tekstem utajonej treści marzenia sennego, rzekomo skrywającej się pod lub za powierzchnią snu. Proces ten wytworzy raczej konstelację rozbitych elementów, z różnych stron

6 Tłumacząc ten przypis, Robert Reszke uległ pokusie uspójnienia metaforyki i wprowadził kategorię pępowiny, która wszakże nie pojawia się w oryginale. Tamże, s. 110. 
odsyłających do mrocznego centrum, aporetycznego pępka, który opiera się rozumieniu, zawiesza porządek symboliczny i stanowi właściwie miejsce pragnienia: nie tyle spełnionego, ile niespodziewanie zaprezentowanego w całej swojej enigmatyczności.

Proponując taką skromną, być może zawstydzająco oczywistą rewizję schematycznego odczytania Freudowskiej procedury hermeneutycznej, znów korzystam po trosze z podpowiedzi lacanistów7, przede wszystkim jednak idę w ślad za teorią konstelacji nakreśloną przez Waltera Benjamina. W metodologicznej przedmowie do swojej niedoszłej rozprawy habilitacyjnej zatytułowanej Źródło dramatu żałobnego w Niemczech Benjamin stwierdza, że „idee” - których prezentacja stanowi właściwy cel „traktatu filozoficznego" mają się do krytycznie rozbitych i przegrupowanych elementów zjawisk „tak jak gwiazdozbiory mają się do gwiazd"8. Idea jest zatem pewnym kształtem wyłaniającym się z konstelacji fenomenów poddanych analizie za pomocą pojęć. Wszelako kilka linijek niżej, nieco modyfikując obrazowanie, Benjamin każe nam potraktować idee jako „faustowskie matki”, Goetheańskie ideały czy prafenomeny, które krystalizują się w centrum pewnego pola sił rozpiętego między konceptualnie opracowanymi elementami zjawisk. Elementy te zresztą winny mieć charakter skrajny, nie zaś przeciętny, dopiero wówczas bowiem konstelacja okazuje się prawdziwie płodna pod względem poznawczym: „Tak jak matka ewidentnie zaczyna żyć pełnią życia dopiero z chwilą, kiedy dzieci, czując jej bliskość, otaczają ją wianuszkiem, tak też idee nabierają życia dopiero wtedy, gdy zgromadzą się wokół nich skrajności"9. Idea jest więc kształtem, zasadą jedności, a zarazem właściwym centrum konstelacji rozbitych i przegrupowanych zjawisk.

Zrewidowaną, bardziej dramatyczną wersję Benjaminowskiej teorii konstelacji można odnaleźć w metodologicznych notatkach do niedokończonych Pasaży. Wedle tego późniejszego ujęcia, w krytycznym, ulotnym momencie poznania dziejowego historyk wprowadza swoją teraźniejszość w konstelację z elementami niegdysiejszych zjawisk, które dopiero w jego czasach osiągają próg wyższej czytelności. Skutkiem tej procedury jest gwałtowna

7 Prócz wspomnianej wyżej myśli, że pragnienie pojawia się tylko na powierzchni, inspiracji lacanowskiej (a ściślej: žižkowskiej) zawdzięczam myśl, że sen prezentuje pragnienie, lecz nie pragnienie spełnione. Zob. S. Žižek Patrzq̨cz ukosa, przeł. . Margański, KR, Warszawa 2003, s. 18.

8 W. Benjamin Źródło dramatu żałobnego w Niemczech, przeł. A. Kopacki, Sic!, Warszawa 2013, S. 17.

9 Tamże. 
krystalizacja „obrazu dialektycznego", jak obecnie nazywa Benjamin „ideę”, a dokładniej jej manifestację w dziejach, którą wcześniej określał mianem „źródła”: „Obraz jest tym, w czym «byłość» piorunowym błyskiem tworzy konstelację z «teraz». Inaczej mówiąc, obraz to znieruchomiała dialektyka. [...] Obraz odczytany, tj. obraz w «teraz» poznawalności, nosi na sobie w stopniu najwyższym piętno momentu krytycznego, niebezpiecznego, leżącego u podstaw wszelkiej lektury"10. I to właśnie w Pasażach Benjamin - od zawsze zainteresowany światem marzenia sennego - starał się powiązać tę konstelacyjną epistemologię z problematyką snu: na badane zjawiska historyczne minionej epoki starał się spojrzeć jak na kolektywne marzenie senne, a ów krytyczny moment lektury utożsamiał z momentem przebudzenia. Stąd już niedaleko było do zrównania historyka z dziedzicem biblijnego Józefa: „W obrazie dialektycznym byłość pewnej określonej epoki jest jednocześnie «byłością-od-zawsze». Ale jako taka objawia się ona każdorazowo tylko oczom konkretnej, określonej epoki: mianowicie tej, w której ludzkość, przecierając oczy, rozpoznaje ten obraz ze snu jako taki właśnie. W tym momencie historyk bierze na siebie zadanie wykładacza snów (die Aufgabe der Traumdeutung)"11. Jeśli więc tekst Freudowskiego dzieła o objaśnianiu marzeń sennych sam nakłania nas do rewizji zbyt prostej procedury hermeneutycznej, którą nominalnie formułuje się w owym tekście, to teksty Benjamina zapraszają nas do tego, byśmy ową rewizję przeprowadzili w duchu teorii konstelacji, utożsamiając Benjaminowski obraz dialektyczny (czyli źródło albo konkretną obecność idei) z Freudowskim pępkiem snu jako właściwym miejscem pragnienia, ukazującym się w konstelacyjnym polu sił rozpiętym między elementami marzenia sennego ${ }^{12}$.

Jeśli pozwolimy sobie na taki eksperyment, otworzy się przed nami droga do atrakcyjnej rewizji, a przynajmniej do pogłębionego rozumienia myśli samego Benjamina. Gdy w przedmowie do książki o dramacie żałobnym Benjamin rozwija koncepcję myślenia konstelacjami, wznosi ją na fundamencie swojej teorii języka naszkicowanej po raz pierwszy w eseju $O j e ̨ z y k u$ w ogóle i o języku człowieka ${ }^{13}$. Tak więc „idea” zostaje utożsamiona z „imieniem”.

10 W. Benjamin Pasaże, przeł. I. Kania, Wydawnictwo Literackie 2005, fr. [N 3, 1], s. 509.

11 Tamże, fr. [N 4, 1], s. 510-511.

12 Jeśli chodzi o klasyczną próbę ukazania roli, jaką w myśleniu Benjamina odgrywało dzieło Freuda, zob. S. Weigel Body-and Image-Space. Re-reading Walter Benjamin, trans. G. Paul, Routledge, London 1996, zwłaszcza s. 99-133.

Zob. W. Benjamin O języku w ogóle i o języku człowieka, przeł. A. Lipszyc, w: tegoż Konstelacje, 
W ujęciu Benjamina imię to monadyczny kwant tego aspektu języka, który wykracza poza jego funkcję przekazu znaczenia, ułamek samej jego „językowości". Choć jednak w imieniu język wydaje się pojednany z samym sobą - jest tylko samym sobą i niczym więcej - to w tym właśnie punkcie i dokładnie po to, by odsłoniła się sama jego językowość, musi on także przestać działać i ogłosić strajk wobec swoich znaczeniowych i komunikacyjnych zatrudnień. Innymi słowy, imię jest szczytowym punktem języka, a zarazem otchłanią, w której znaczenie zapada się w żywioł aporetyczności ${ }^{14}$. W późniejszym eseju poświęconym "nauce o podobieństwie" Benjamin wyjaśnia, że "magiczny" (tj. imienny) aspekt języka pojawia się jedynie na podłożu i powierzchni aspektu „semiotycznego" (tj. znaczeniowego) jako pewien rebus, zagadka obrazkowa (Vexierbild), ulotna konstelacja elementów odczytywanych w krytycznym momencie ${ }^{15}$. Jeśli jednak imię jest tym, czym jest - tj. nie tyle momentem znaczenia, ile otchłannym momentem samej językowości języka - to uchwycenie prafenomenu, krytyczne wydobycie konstelacji jako konstelacji oznacza nie tyle rozwiązanie zagadki, ile ujrzenie jej jako zagadki właśnie. To zaś oznacza, że potrafimy ujrzeć w niej miejsce, gdzie rozumienie staje dęba i ulega paraliżowi' ${ }^{16}$.

przeł. A. Lipszyc, A. Wołkowicz, Wydawnictwo UJ, Kraków 2012, s. 1-18.

Ujmując rzecz w ten sposób, podążam za interpretacjami Wernera Hamachera. Zob. przede wszystkim jego fundamentalny esej Afformative, Strike, trans. D. Hollander, w: A. Benjamin, P. Osborne (eds.), Walter Benjamin's Philosophy: Destruction and Experience Clinamen Press, London 2000, s. 108-137, a także Gest w imię. Benjamin i Kafka, przeł. M. Stefański, w: Ł. Musiał, A. Żychliński Nienasycenie. Filozofowie o Kafce, Korporacja Ha!art, Kraków 2011, s. 269-322.

15 Zob. W. Benjamin Nauka o podobieństwie, przeł. A. Lipszyc, w: tegoż Konstelacje, s. 219.

Te logikę znakomicie uchwycił Theodor Adorno w swojej później teorii dzieła sztuki i jego „zagadkowej" natury. W Teorii estetycznej czytamy: „Estetyka nie może pojmować dzieł sztuki jako obiektów hermeneutycznych; pojąć należałoby, z dzisiejszej perspektywy, ich niepojętość" (s. 217). Kilka stron dalej Adorno błyskotliwie igra z Benjaminowską ideą Vexierbild i z Freudowską koncepcją snu jako rebusu (sam Freud posługuje się terminem Bildrätsel, zagadka obrazkowa): „Dzieła sztuki są zagadkami. Zawierają one potencjalnie rozwiązanie, ale nie jest ono ustanowione obiektywnie. Każde dzieło sztuki jest obrazem z ukrytymi figurami (Vexierbild), ale w taki sposób, że pozostaje ono na etapie drwiny i drażnienia (Vexieren), na etapie wprzód ustanowionej klęski odbiorcy" (s. 223; przekład zmodyfikowany). Wreszcie, nawiązując do Benjaminowskiej definicji aury jako spojrzenia przedmiotu i (raczej bezwiednie) zbliżając się do Lacanowskiej charakterystyki "obiektu małe a", Adorno pisze: „Rozwiązać zagadkę to tyle, co podać powód jej nierozwiązywalności: spojrzenie, którym dzieła sztuki patrzą na odbiorcę" (s. 224). T.W. Adorno Teoria estetyczna, przeł. K. Krzemieniowa, PWN, Warszawa 1994, s. 217, 223 , 224 . 
Jeśli Benjamin zrównywał imię z ideą pojętą jako centrum konstelacji, ja zaś pozwoliłem sobie postawić znak równości między ideą i Freudowskim pępkiem snu, to nie pozostaje mi nic innego, jak wprost utożsamić ów pępek $\mathrm{z}$ imieniem. Wobec powyższej charakterystyki imienia, takie posunięcie wydaje się wszakże jak najbardziej sensowne. Imię to pępek, dziwna rzecz ukazująca się jedynie w samym środku porządku znaczeń, lecz tylko tam, gdzie porządek ten się zapada - na końcu języka - w zawrotnym punkcie, który jest celem wszelkiej Deutung, lecz który sam w sobie pozostaje całkowicie undeutbar, odporny na objaśnianie. Dzięki takiemu utożsamieniu możemy też zwrócić uwagę na inną cechę imienia. Jak bowiem pamiętamy, pępek marzenia sennego to nie tylko hermeneutyczny wir blokujący wszelkie rozumienie, lecz także właściwe locus ostatecznego pragnienia. Jeśli więc powiążemy ze sobą Benjamina i Freuda, samo imię ukaże swój aspekt libidinalny. W chwilach przebudzenia, w momencie krytycznego rozpoznania, gdy udaje nam się rozbić ideologiczną powierzchnię porządku symbolicznego, którą nazbyt wygładziło opracowanie wtórne, w unikalnych konstelacjach zjawisk, gdzie rozumienie staje dęba, dana nam jest ulotna wizja imienia-jako-pępka-snu, wówczas zaś naszym oczom ukazuje się obraz naszego ostatecznego pragnienia, którego obiekt antycypowany jest w konstelacyjnej kontemplacji antycypowany jako coś, co nadchodzi, lecz nigdy nie jest po prostu dane.

Nie odwołując się do Freuda, Benjamin brał czasem pod uwagę ów libidinalny aspekt imienia. I tak np. w dwóch zapiskach zatytułowanych, odpowiednio, Miłość platoniczna i Za blisko imię zostaje zaprezentowane jako sam rdzeń obiektu miłości. Ważniejsze jednak wydaje się inne, mniej bezpośrednie powiązanie między imieniem i sferą libidinalną17. We wcześniejszej wersji przedmowy do książki o dramacie żałobnym - w której skądinąd idea konstelacji jeszcze się nie pojawia - Benjamin nieco bardziej otwarcie niż w wersji ostatecznej igra z teologicznym wymiarem swej teorii. Także w wersji ostatecznej imienny aspekt języka uchwytywany w poznaniu konstelacyjnym utożsamia Benjamin z językiem, którym Adam mówił w raju; w wersji wcześniejszej ów język sprzed Upadku jawnie utożsamia się z objawieniem. Co jednak ważniejsze w kontekście niniejszych rozważań, w tym bardziej ezoterycznym zapisie Benjamin rozwija pewną szczególną logikę, która rządzi manifestacją imion ${ }^{18}$. Jeśli idea manifestuje się w dziejach jako „źródło”,

17 Zob. W. Benjamin Kurze Schatten I, w: tegoż Gesammelte Schriften, Suhrkamp Verlag, Frankfurt am Main 1991, t. 4, s. 368-370. 
to - twierdzi Benjamin - wszystko, co źródłowe, jest „niepełną restauracją” rajskiego/adamowego/imiennego objawienia. Jest restauracją, ponieważ odsłania imię; jest restauracją niepełną, ponieważ z istoty swojej uczestniczy w przygodności dziejów. Oba momenty pozostają wszakże w dialektycznym splocie. Z jednej strony tylko dzięki owej niepełności wymuszonej przez dziejowość źródło może ukazać się jako restauracja objawienia, tak jak nominalny aspekt języka może ukazać się jedynie na podłożu jego aspektu znaczeniowego. Z drugiej jednak strony moment źródłowy uzyskuje prawdziwie dziejową pojedynczość, przestaje być tylko przygodnym zjawiskiem reprezentującym ogólniejszą klasę, staje się zaś czymś prawdziwie wyjątkowym - właśnie dzięki ujawniającemu się w nim aspektowi restauracji. Analiza tej dialektyki prowadzi Benjamina do tezy, która wydaje się najistotniejsza dla naszych celów. Twierdzi on mianowicie, że każde źródło jest czymś niepowtarzalnym i powtórzonym zarazem, że określone jest i rozdzierane przez antynomię jednorazowości i repetycji, które nawzajem się determinują - to zaś skądinąd sprawia, że jest ono z zasady czymś enigmatycznym (geheimnisvoll), choć pewnie lepiej byłoby rzec: aporetycznym.

Otóż ten sam splot nowości i powtórzenia w rozmaitych rekonfiguracjach powraca nieustannie w późniejszych pismach Benjamina, zwłaszcza tych poświęconych doświadczeniu miejskiemu i doświadczeniu dzieciństwa. W szczególności, w enigmatycznym szkicu zatytułowanym Agesilaus Santander Benjamin odwołuje się do tej logiki, by zdefiniować pewną szczególną kategorię. Pisze tutaj mianowicie o swoim "nowym aniele" ze słynnego obrazu Paula Klee: „Pragnie szczęścia: sprzeczności między ekstazą tego, co jednorazowe, nowe, jeszcze nie przeżyte, a ową błogością drugiego razu, ponownego posiadania, tego, co przeżyte" ${ }^{\text {"19 }}$. A zatem to szczęście określane jest przez antynomię jednorazowości i powtórzenia - i to właśnie pragnienie nigdy-na-dobre-nie-nadchodzącego, wciąż-wymykającego-się szczęścia tworzy rdzeń owych marzeń sennych minionego pokolenia, które stanowią właściwy przedmiot konstelacyjnych studiów podejmowanych w Pasażach. Ostatecznie zatem proponuję przyjąć, że aporetyczny, blokujący rozumienie punkt imienia-jako-pępka-snu jest miejscem pragnienia szczęścia, które rządzi się ową szczególną logiką źródła, logiką jednorazowości i powtórzenia. Imię jest i nie jest obiektem tego pragnienia: wyznacza ono miejsce, gdzie owego

19 W. Benjamin Agesilaus Santander, tekst przytoczony w całości w eseju Gershoma Scholema Walter Benjamin i jego anioł, przeł. A. Lipszyc, w: tegoż Żydzi i Niemcy, przeł. M. Zawanowska, A. Lipszyc, Pogranicze, Sejny 2006, s. 239. 
obiektu dośwadcza się jako nadchodzącego, lecz nigdy nie danego, miejsce, gdzie w zawrotnym wirze język otwiera się na antycypowany obiekt, który jest zarówno nowy, jak i dojmująco znajomy.

Po to jednak, by w pełni uchwycić logikę imienia-jako-pępka-snu, musimy ponownie zwrócić się ku myśli Freuda. Dokładnie rzecz biorąc, warto przyjrzeć się mistrzowskiemu oczytaniu Trzech esejów z teorii seksualnej, jakie zaproponował Jean Laplanche. Francuski psychoanalityk zwraca uwagę na kluczową rolę, jaką we wczesnej fazie rozwoju Freudowskiej teorii w ogóle, a w tekście Trzech esejów w szczególności, odgrywała idea „oparcia” (Anlehnung). Rdzeniem tej idei jest myśl, że popęd seksualny pojawia się zrazu jako coś w rodzaju efektu ubocznego, pasożytniczego czy spektralnego mechanizmu opartego na instynkcie samozachowawczym, skłaniającym dziecko do tego, by ssać pierś matki. Zdefiniowane w ten sposób widmo seksualności uzyskuje samoistność w momencie, gdy oralny autoerotyzm dziecka ma zrekompensować utratę pierwotnego obiektu. W tym jednak punkcie właśnie Laplanche rozpoznaje źródło fundamentalnego paradoksu ludzkiej seksualności. Najpierw przytacza zasadniczy fragment trzeciego z Freudowskich esejów, następnie zaś opatruje go błyskotliwym komentarzem. Pisze Freud:

Kiedy najpierwsze zaspokojenie seksualne związane było jeszcze z przyjmowaniem pokarmu [Laplanche dodaje w tym miejscu: $\mathrm{tj} . \mathrm{w}$ fazie oparcia- przyp. A.L.], popęd seksualny miał obiekt znajdujący się poza własnym ciałem podmiotu w postaci piersi matki. Później popęd stracił ten obiekt, być może akurat wtedy, gdy dziecko uzyskało możliwość wyrobienia sobie całościowego wyobrażenia osoby, do której należał ów zaspokajający narząd. Popęd płciowy staje się w takiej sytuacji z reguły autoerotyczny i dopiero po przezwyciężeniu okresu utajenia ów pierwotny stosunek nawiązuje się na powrót. Nie bez przyczyny ssanie piersi matki staje się dla dziecka wzorem każdego stosunku miłosnego. Znajdowanie obiektu jest zatem właściwie ponownym jego odnalezieniem. ${ }^{20}$

Laplanche zaś komentuje:

Jeśli taki tekst mamy traktować poważnie, oznacza to, że z jednej strony od początku istnieje pewien obiekt, z drugiej 
strony jednak seksualność nie posiada, od samego początku, żadnego rzeczywistego obiektu. Należy zrozumieć, że rzeczywisty obiekt, mleko, był obiektem funkcji odżywczej, przypisanej do świata zaspokojeń. Taki jest ów rzeczywisty obiekt, który został utracony, lecz obiektem popędu seksualnego jest pierś - przerodzona w pierś fantazmatyczną. Tak więc obiekt seksualny nie jest tożsamy z obiektem funkcji odżywczej, lecz jest w stosunku do niego przemieszczony; pozostają one w relacji zasadniczej p r zyl e gło ś c i, która każe nam prześlizgiwać się niemal niezauważalnie od jednego do drugiego, od mleka do piersi jako jego symbolu. „Znajdowanie obiektu”, konkluduje Freud (a sformułowanie to stało się tymczasem słynne), ,jest zatem właściwie ponownym jego odnalezieniem". Objaśniłbym to następująco: obiekt, który ma być ponownie odnaleziony, nie jest obiektem utraconym, lecz jego zastępnikiem na mocy przemieszczenia; utracony obiekt jest obiektem instynktu samozachowawczego, przedmiotem głodu, obiekt zaś, który staramy się odzyskać w seksualności, jest przemieszczony w stosunku do tego pierwszego obiektu. Stąd, rzecz jasna, bierze się ostateczna niemożność ponownego odnalezienia obiektu, ponieważ obiekt, który został utracony, nie jest ty m s a mym, który ma zostać ponownie odnaleziony. Tu właśnie kryje się klucz do zasadniczego „fałszu” ulokowanego u samych źródeł naszych seksualnych dążeń. ${ }^{21}$

Tak więc zgodnie z tą fascynującą interpretacją popęd seksualny u swych początków opiera się na insynkcie samozachowawczym, kończy zaś jako clinamen, perwersja instynktu, wykolejone dążenie, które zbacza z drogi natury w dziedzinę fantazmatów. W szczególności, Laplanche pokazuje, że nasze dążenia seksualne naznaczone są gorzką ironią: seksualność zaczyna się na dobre od utraty obiektu, lecz rzeczywisty obiekt, który istniał na początku, był przedmiotem głodu, tak więc całe życie rozpaczliwie pragniemy odzyskać coś, czego nigdy w istocie nie mieliśmy. Utracony obiekt puszcza w ruch naszą seksualność i definiuje nasze dążenia, ale to wcale nie za nim się uganiamy. Seksualność to dążenie wyprowadzające nas poza porządek samozachowawczy na pustynię perwersji, gdzie staramy się "odzyskać” coś, co w istocie jest rezultatem fantazmatycznego przemieszczenia tego, co zostawiliśmy za sobą. Stąd też jest to dążenie prawdziwie niemożliwe. Każdy obiekt, jaki możemy

21 J. Laplanche Life and Death in Psychoanalysis, trans. J. Mehlman, The Johns Hopkins University Press, Baltimore 1985, s. 19-20. Wyróżnienia w tekście pochodzą od Laplanche'a. 
odnaleźć w tym smutnym świecie immanencji, musi być z konieczności obiektem niewłaściwym² ${ }^{22}$.

Jeśli rzecz sformułuje się w ten sposób, logika ta jest oczywiście głęboko pesymistyczna. A jednak tę właśnie logikę proponuję powiązać z ową logiką jednorazowości i powtórzenia, którą Benjamin rozwija w swojej teorii źródła i w swoich uwagach o pojęciu szczęścia. Nie twierdzę bynajmniej, że te dwie logiki są izomorficzne. Zgodnie ze schematem Benjaminowskim imię - które utożsamiłem z momentem pragnienia - to punkt antycypowanej, niepełnej, niespełnionej repetycji rajskiej błogości, powtórzenia urzeczywistnianego w jednorazowej konstelacji elementów immanentnego świata zjawisk. Zgodnie ze schematem Freudowskim nasze pragnienie jest określone jako niemożliwe dążenie do powtórzenia czegoś, czego nigdy nie było, ponieważ tym, co było na początku, był tylko obiekt tego nudnego, biologicznego instynktu samozachowania - nawet jeśli to utrata tego właśnie obiektu uruchomiła naszą seksualność. To odmienne schematy i odmienne sposoby myślenia. Wszelako ich kombinacja w ramach bardziej pojemnej logiki może zaowocować zarówno odświeżającym odczarowaniem teologicznie ugruntowanych konstrukcji Benjamina, jak i zbawiennym dopełnieniem głęboko pesymistycznej, niemal sarkastycznej koncepcji Freuda.

Zgodnie z tą bardziej pojemną logiką w punkcie zwanym imieniem albo pępkiem marzenia sennego, który identyfikuje się w ramach procesu Deutung, porządek znaczeń doznaje zapaści. W tym miejscu odsłania się coś, co (jeszcze) nie istnieje, przedstawia się więc jako coś nadchodzącego, nie zaś danego. Obiekt ten ukazuje się wyłącznie w jednorazowej konstelacji fragmentów zdekomponowanej immanencji. Przy całej swej jednorazowości jawi się on zarazem jako repetycja, ponowne odnalezienie czegoś, czego wszakże - wbrew Benjaminowskim fantazjom o rajskiej egzystencji - nigdy w istocie nie mieliśmy. Tym, co mieliśmy - i utraciliśmy - był nader prozaiczny porządek samozachowawczy czy też - by posłużyć się językiem biblijnym - bezmyślny świat egipskich garnców mięsiwa. Nasze erotyczne pragnienie opierało się na naszym głodzie, teraz jednak wyprowadza nas na pustynię ku Ziemi Obiecanej. Nie znamy tej Ziemi, tak jak i nigdy nie wygnano nas z raju, w istocie bowiem wzrośliśmy (krzywo) z egipskiej gleby instynktu.

Koncepcję Laplanche'a wykorzystuje w swojej teorii poezji Harold Bloom, przeprowadzając błyskotliwą analogię między instynktem samozachowawczym i znaczeniem dosłownym $z$ jednej strony oraz między popędem seksualnym i „zboczonym" znaczeniem figuratywnym $z$ drugiej. Zob. H. Bloom The Breaking of the Vessels, The University of Chicago Press, ChicagoLondon 1982, s. 42-70. 
Obiekt naszych pragnień może być tylko przemieszczonym, fantazmatycznym obrazem przedmiotu zaspokojenia funkcji samozachowawczych, zautonomizowanym za sprawą utraty tego przedmiotu. Wizja Edenu jest retroaktywną fantazją o tym, jakby to było, gdyby popęd erotyczny istniał od samego początku bez mechanizmu oparcia: pławiłby się w błogości czystego języka. A przecież język imion nie może być czysty. Albowiem, raz jeszcze i w jednej formule: imię-jako-pępek-snu może pojawić się jedynie jako konstelacja elementów porządku semiotycznego, w punkcie jego aporetycznego załamania, jako antycypowany obiekt zboczonego pragnienia kształtowanego podług fantazji o utraconym raju, lecz zmierzającego ku nadchodzącej utopii szczęścia - utopii odzyskania rzeczy, której nigdy nie mieliśmy.

Jak pamiętamy, mówiąc o „pępku snu”, Freud posługuje się określeniem „kłąb myśli sennych" (ein Knäuel von Traumgedanken). Otóż w całej książce o objaśnianiu marzeń sennych słowo Knäuel występuje jeszcze tylko jeden jedyny raz i to w bardzo podobnym złożeniu: ein Knäuel von Gedanken (czyli po prostu: kłąb myśli). Na frazę tę natrafiamy we fragmencie nieco wcześniejszym niż akapit poświęcony pępkowi marzenia sennego; także i on przykuł uwagę wielu komentatorów, już choćby dlatego, że Freud nader otwarcie mówi tutaj o swojej żydowskości²3. Passus ten poświęcony jest analizie pewnego marzenia sennego: rozpoczyna się ono sceną, w której „profesor M.” mówi: „Mój syn, Myop...", następnie zaś przeobraża się w enigmatyczną opowieść o prześladowaniu i ocaleniu. Analiza zapisu tego snu oraz objaśnień zaproponowanych przez Freuda może zilustrować, pogłębić i dopełnić powyższy wywód. Oto więc zapis samego marzenia:

Z powodu jakichś wydarzeń, do których doszło w Rzymie, trzeba ewakuować dzieci - co też się dzieje. Następna scena rozgrywa się przed jakąś bramą, podwójną bramą (Doppeltor) zbudowaną na antyczną modłę (to Porta Romana w Sienie, o czym wiem jeszcze we śnie). Siedzę na cembrowinie fontanny (Brunnen), jestem bardzo smutny, niemal płaczę. Jakaś kobieta - pielęgniarka, zakonnica - przyprowadza dwóch chłopców i przekazuje ich ojcu, którym nie jestem ja. Starszy z nich to wyraźnie mój najstarszy syn, twarzy drugiego nie widzę; kobieta, która przyprowadziła

23 Zob. np. D. Boyarin Unheroic Conduct: The Rise of Heterosexuality and the Invention of the Jewish Man, University of California Press, Berkeley-Los Angeles-London 1997, s. 221-229; Y.H. Yerushalmi Freud's Moses: Judaism Terminable and Interminable, Yale University Press, New HavenLondon 1991, s. 12, 69-70. 
chłopca, żąda odeń pocałunku na pożegnanie. Charakteryzuje się ona czerwonym nosem. Chłopiec wzbrania jej pocałunku, mówi jednak, podając jej rękę na pożegnanie: „Auf Geseres”, a do nas dwóch (czy też do jednego z nas): „Auf Ungeseres”. Przychodzi mi do głowy, że to ostatnie to coś lepszego. ${ }^{24}$

Freud przedstawia nader niekompletną i dyskusyjną interpretację tego marzenia. Przede wszystkim otwarcie wskazuje przeżycie, które zapewne bezpośrednio ów sen sprowokowało: miałby nim być spektakl teatralny, który Freud obejrzał na krótko wcześniej i który wywołał w nim istny Knäuel von Gedanken. Idzie o inscenizację sztuki Das neue Ghetto [Nowe getto], autorstwa Theodora Herzla, przywódcy ruchu syjonistycznego - dramatu poświęconego dylematom Żydów w nowoczesnym społeczeństwie i „nowemu gettu” antysemickiej wrogości, które zastępuje dawne getto sprzed czasów emancypacji. Strapiony Freud wyznaje, że jego sen z całą pewnością związany jest z jego troską o przyszłość dzieci, którym nie potrafi zapewnić ojczyzny, i troską o takie ich wychowanie, „by mogły swobodnie zmieniać miejsce pobytu" - a swoje wyznanie puentuje melancholijnym cytatem z Księgi Psalmów („Nad rzekami Babilonu - tam siedzieliśmy i płakali”) ${ }^{25}$.

To jednak tylko punkt wyjścia do dalszej interpretacji. Freud wskazuje, że właśnie w Sienie widział krótko wcześniej zakład psychiatryczny, a owo wspomnienie łączy następnie $\mathrm{z}$ faktem, że pewien jego Glaubensgenosse (towarzysz w wierze, współwyznawca) musiał ostatnio zrezygnować z posady w takiej instytucji. Termin Glaubensgenosse mógłby wskazywać, że Freud kontynuuje wątek żydowski. Co najmniej tak samo przekonująca wydaje się sugestia, że Freud - „bezbożny Żyd” - może czynić tu aluzję do dowcipnej frazy Heinricha Heinego, który Barucha Spinozę określił mianem swego Unglaubensgenosse (towarzysza w niewierze), i że zatem ów towarzysz, którego ma na myśli Freud, to raczej jego brat w psychoanalizie (choć najpewniej żydowskiego pochodzenia). Rzecz wydaje się trudna do rozstrzygnięcia ${ }^{26}$.

Po tych wstępnych uwagach Freud koncentruje się na parze Geseres-Ungeseres. Jak tłumaczy, nieco tajemniczy Schriftgelehrte (uczeni w piśmie)

24 S. Freud Objaśnianie marzeń sennych, s. 375. Przekład zmodyfikowany.

25 Tamże.

Sugestię tę wysuwa tłumacz Freuda, Robert Reszke (tamże). Reszke zwraca uwagę, że Freud przywołuje kalambur Heinego w książce o dowcipie. Zob. S. Freud Dowcip i jego stosunek do nieświadomości, w: tegoż Pisma psychologiczne, przeł. R. Reszke, KR, Warszawa 1997, s. 73. 
poinformowali go, że Geseres to hebrajskie słowo, które można przełożyć jako „nakazane cierpienie, nieszczęście”, lecz które w jidysz oznacza „lamenty i skargi". Słowo Ungeseres nie istnieje, lecz niemiecki przedrostek sugeruje oczywiście negację. Kiedy jednak - pyta Freud - negacja jest zaletą? Jego odpowiedź jest dość zaskakująca. Jest tak ponoć w przypadku kawioru: niesolony kawior ceni się wyżej niż solony. Nie ujawniając szczegółów, Freud stwierdza, że jest to aluzja do jednej z jego domowniczek, która - jako młodsza od niego - miałaby w przyszłości zaopiekować się jego synami. A jednak, tłumaczy Freud cokolwiek nieprzekonująco, przejście od pary Geseres-Ungeseres do pary gesalzen-ungesalzen (solony-niesolony) wymaga jeszcze jednego połączenia czy też stacji pośredniej. Tego brakującego ogniwa dostarcza tradycja pesachowa i para słów gesäuert-ungesäuert (kwaszony-niekwaszony), w której także to, co zanegowane, ma przewagę: na Pesach, święto upamiętniające Wyjście z Egiptu, Żydzi jedzą wszakże tylko chleb bez zakwasu.

Od tego punktu kręta droga skojarzeń wiedzie Freuda dalej przez wspomnienie o spotkaniu z Wilhelmem Fliessem, do którego doszło we Wrocławiu pewnej Wielkanocy (która skojarzyła się Freudowi z Pesach jako chrześcijański odpowiednik tego żydowskiego święta), obraz dziecka pytającego niewłaściwych ludzi o drogę, komiczny szyld: „Dr Herod - godziny przyjęć...”, spekulacje Fliessa dotyczące tego, jakby to było mieć tylko jedno oko „jak cyklop”, a tym samym do wyjściowej frazy „Mój syn, Myop” i czegoś, co Freud rozpoznaje jako "główne źródło słowa Geseres" ${ }^{27}$. Miałoby nim być wspomnienie dotyczące syna owego profesora M., który to syn w dzieciństwie cierpiał na infekcję oka. Lekarz starał się uspokoić matkę, dowodząc, że dopóki zakażenie jest jednostronne, nie ma powodu do obaw. Oko zostało wyleczone, ale wkrótce potem zapalenie pojawiło się w drugim, co przeraziło matkę chłopca. Lekarz wszakże wydrwił jej Geseres (lamenty) i zapewnił, że wszystko będzie dobrze. Otóż, ponieważ szkolna ławka, która należała do tamtego chłopca, została podarowana pierworodnemu Freuda, ojciec psychoanalizy ostatecznie dochodzi do wniosku, że owo marzenie senne wyraża jego pragnienie, by syn rozwijał się bezpiecznie i w sposób harmonijny, wolny od wszelkiej jednostronności.

Omawiając mechanizm opracowania wtórnego, które - cokolwiek na ślepo i arbitralnie - komponuje ostateczną narrację snu z osobliwych, zniekształconych fragmentów, Freud pisze: „Z pewnością to nie żadna inna instancja psychiczna, jak tylko nasze normalne myślenie przystępuje do treści

Tamże, s. 376. 
sennej z roszczeniem, by była ona zrozumiała; to właśnie ona [w procesie opracowania wtórnego - przyp. A.L.] poddaje ją pierwszemu objaśnieniu (Deutung), wskutek czego wprowadza doń kompletne niezrozumienie"28. Właściwa Deutung musi oczywiście przeciwstawić się temu procesowi. Otóż czasem można odnieść wrażenie, że objaśnienia własnych snów, jakie podaje Freud, same mają coś z owej „pierwszej Deutung”, którą należy czym prędzej zdemontować. Tak jest chyba w przypadku snu skupionego wokół pary Geseres-Ungeseres. W szczególności warto zwrócić uwagę na sposób, w jaki Freud obchodzi się tutaj z „kwestią żydowską”. W jego rozumowaniu pojawia się ona jedynie jako bezpośredni punkt wyjścia (sztuka Herzla) lub jako most czy ogniwo w łańcuchu skojarzeń (Glaubensgenosse, gesäuert-ungesäuert, Pesach). Wydaje się, że Freud nie tyle skrywa żydowskie motywy tego marzenia sennego, ile odsłania je po to tylko, by wytłumić je tym skuteczniej, ostatecznie przechodząc do kwestii natury prywatnej i uniwersalnej zarazem: do pragnienia, by znalazł się ktoś, kto zaopiekuje się jego synami, oraz pragnienia, by jego syn nie wyrósł na człowieka ,jednostronnego". Sporo jednak wskazuje na to, że właśnie owe kwestie żydowskie odgrywają o wiele ważniejszą i o wiele bardziej dwuznaczną rolę w marzeniu sennym Freuda.

Przede wszystkim należy prześledzić wątek, którego sam Freud dotyka jedynie przelotnie. Choć „akcja” snu rozgrywa się w Sienie, wszystko dzieje się przed Porta Romana, po tym jak większość osób tego sennego dramatu uciekła z Rzymu. Freud przechodzi do porządku nad tym szczegółem, wspominając jedynie, że ponieważ nie był jeszcze w Rzymie, potrzebował dlań jakiegoś substytutu. To z pewnością niewystarczające objaśnienie, pomija bowiem rolę, jaką Rzym odgrywa w uniwersum jego wyobrażeń i pragnień. We wcześniejszym fragmencie ojciec psychoanalizy opowiada, jak to z jakiegoś powodu nie może dotrzeć do Rzymu - i przedstawia sekwencję snów wyrażających pragnienie, by się tam znaleźćc ${ }^{29}$. W jednym z nich widzi Rzym z oddali niczym ziemię obiecaną. W innym czuje, że znalazł się w samym mieście, nie widzi jednak jego scenerii, naruszając więc koncepcję snu jako spełnienia życzeń, musi przyznać, że w tym marzeniu „daremnie” stara się ujrzeć Wieczne Miasto. To marzenie senne przywodzi na myśl sen, który Walter Benjamin opisuje we wspomnianym wcześniej zapisku, zatytułowanym Za blisko.W tym śnie Benjamin ma pewność, że znalazł się w Paryżu, tuż przy Notre Dame, katedra jednak wygląda na dziwnie zniekształconą. Benjamin

28 Tamże, s. 421.

Tamże, s. 177-179. 
odczuwa naraz wielką, lecz błogą tęsknotę, nie tyle jednak za czymś, co jest daleko, ile za czymś, do czego podszedł za blisko - a co w związku z tym utraciło obraz i zostało sprowadzone do imienia ${ }^{30}$. Wydaje się zatem, że również w swoim śnie Freud podszedł zbyt blisko do obiektu swoich pragnień, co wszakże skutkuje nie tyle uczuciem błogości, ile lękiem. Wreszcie Freud identyfikuje coś, co uważa za najgłębsze, infantylne źródło swego pragnienia dotarcia do Rzymu. Otóż jeśli przed chwilą utożsamił Rzym z Ziemią Obiecaną, siebie samego przedstawiając jako Mojżesza na górze Nebo, teraz schemat ten ulega odwróceniu. Freud stwierdza, że za sprawą doskwierającego mu antysemityzmu począł w dzieciństwie utożsamiać się z Semitą Hannibalem walczącym przeciw Rzymowi. Z tej perspektywy Wieczne Miasto okazuje się nie tyle Syjonem (którego nazwa pobrzmiewa może w nazwie Sieny), ile samym centrum opresyjnego imperium, a pragnienie Freuda okazuje się pragnieniem destrukcji wrogiej potęgi.

Ta ambiwalencja, wahanie między obrazami Rzymu jako Syjonu i Rzymu jako ośrodka wrażego imperium znajduje odzwierciedlenie w motywie dwoistości, który przenika sen o Geseres-Ungeseres. W tym kontekście należy z pewnością wspomnieć o nieustannych rozważaniach nad tym, że należy mieć dwoje (zdrowych) oczu, o podwójnej bramie, Doppeltor - podwójnej Torze? - wreszcie zaś o wspomnianej dwuznaczności słowa Glaubensgenosse, oznaczającego bądź to współwyznawcę, bądź to pobratymca w niewierze ${ }^{31}$. Co najważniejsze jednak, osobliwa dwuznaczność cechuje enigmatyczne hasło Auf Ungeseres. Kimkolwiek bowiem byli uczeni w Piśmie, do których zwrócił się Freud w sprawie znaczenia słowa Geseres, nie przekazali mu pełnych danych na temat pola sematycznego zakreślanego przez korzeń $g z r^{32}$. Wydaje się

30 Zob. W. Benjamin Kurze Schatten I, w: tegoż Gesammelte Schriften, t. 4, s. 370.

Skojarzenie słów Tor i Tora zawdzięczam Danielowi Boyarinowi (zob. przypis 23). Podążając za wcześniejszymi komentatorami tego snu, Boyarin wskazuje także, że podczas analizy tego snu Freud popełnia dość zdumiewającą pomyłkę: wrocławskie spotkanie z Fliessem odbyło się nie podczas Wielkanocy, lecz podczas Bożego Narodzenia (zob. S. Freud Aus den Anfängen der Psychoanalyse. Briefe an Wilhelm Fliess, S. Fischer Verlag, Frankfurt am Main 1975, s. 203-206). Boyarin słusznie przypomina, że to oczywiście z Bożym Narodzeniem wiąże się historia o Herodzie jako prześladowcy dzieci, która - co więcej - kończy się nie tyle wyjściem z Egiptu, ile ucieczką do Egiptu. Tym samym nawarstwiają się kolejne dwoistości: judaizm/chrześcijaństwo, Egipt jako miejsce opresji/Egiptu jako miejsce ocalenia. Można też jednak dowodzić, że popełniając ów błąd, Freud mimowolnie uwypukla właśnie swoje przywiązanie do imaginarium żydowskiego, nawet jeśli w jego opowieści Pesach zostaje zastąpione przez Wielkanoc. 
bowiem, że znaczenia przynależne do tego pola można pogrupować w dwie odrębne, skonfliktowane serie. Z jednej strony zatem korzeń ten odsyła do znaczeń związanych z prześladowaniem Żydów, począwszy od paradygmatycznych prześladowań w Egipcie. Z drugiej strony wszakże odnosi się on do surowych nakazów Prawa pochodzącego od samego Boga lub od autorytetów religijnych, aż po specyficzne i emblematyczne prawo obrzezania. Jeśli weźmie się pod uwagę powiązania, jakie sam Freud ustanowił w późniejszych pismach między kastracją, obrzezaniem i ślepotą, jeśli weźmie się pod uwagę jego późniejszą fascynację postacią Mojżesza i historią Wyjścia z Egiptu, trudno pogodzić się z tym, by żydowski wątek analizy tego marzenia sennego urywał się tak raptownie. Zamiast jednak podążać dalej za owym wątkiem, najlepiej chyba wprost dotknąć owego Knäuel, z którego nić ta się wysnuwa ${ }^{33}$.

W swoim śnie Freud siedzi zrozpaczony na brzegu fontanny. Użyte tutaj słowo Brunnen z pewnością oznacza w tym kontekście fontannę, jego pierwsze znaczenie to jednak studnia lub źródło. W Biblii studnie to dobre miejsca, by znaleźć przyszłą żonę (Mojżesz), a przynajmniej żonę dla swego pana (Eliezer). Do wyschniętej studni zawistni bracia wrzucili też jednak Józefa, objaśniacza snów. Lamentujący myśliciel u studni to strapiony ojciec niepewny przyszłości swego pierworodnego syna - czy zostanie zabity podczas rzezi niewiniątek? a może podczas dziesiątej plagi? czy jest Żydem? Egipcjaninem? Rzymianinem? czym chcę, żeby był? czy wciąż jestem jego ojcem? - lecz także objaśniacz snów niepewny skuteczności swoich procedur. Podobnie jak udręczonego ojca-interpretatora, nas, czytelników, także paraliżuje owa dwuoka ambiwalencja podwójnej Tory, prawa Egiptu i prawa Mojżesza, czy wreszcie dwuznaczność między żydowską wiarą i psychoanalityczną niewiarą. Dwoistości te zdają się osiągać apogeum w chwili, gdy syn/niesyn pozdrawia ojca owym niewiarygodnym, błazeńskim i enigmatycznym hasłem Auf Ungeseres, które stanowi pępek i właściwe imię tego snu. Hasło to jest pozbawione sensu, zarazem jednak znaczy aż nazbyt wiele. Zastępując standardowe i spodziewane Auf Wiedersehen, oznacza może, że syn rozstaje się z ojcem na dobre i ten nigdy już go więcej nie ujrzy. Być może też jednak oznacza, że owszem - ci dwaj zobaczą się, gdy skończy się wszelki lament. Albo: gdy nie będzie już Prawa. Ale: którego Prawa? Prawa Mojżesza - i obrzezania (symbolicznej kastracji i oślepienia synów przez ojców) - czy Prawa Egiptu,

33 Jeśli chodzi o kastrację i ślepotę, zob. S. Freud Niesamowite, w: tegoż Pisma psychologiczne, s. 244. Jeśli chodzi o kastrację i obrzezanie, zob. tegoż Człowiek imieniem Mojżesz a religia monoteistyczna, przeł. A. Ochocki, R. Reszke, w: tegoż, Pisma społeczne, KR, Warszawa 1998, s. 460. 
Edomu, Rzymu, Austrii lub wszelkich opresyjnych imperiów tego świata? Czy wrócimy do judaizmu, do naszych towarzyszy w wierze, czy porzucimy go na dobre, podejmując exodus ku całkowitej bezbożności? Wszystkie te ścieżki i możliwości zaplatają się aporetycznie w węzeł i nawzajem trzymają się w szachu. A przecież radosne, wyróżniające pożegnanie pierworodnego - Auf Ungeseres! - to coś więcej niż tylko plątanina, a zarazem blokada znaczeń. To dziwne zawołanie, które zdaje się zwracać ku utopijnym czasom bez praw i lamentów, jest monstrualną hybrydą, która - podobnie jak Kafkowski Odradek - przynależy do dwóch języków naraz i do żadnego z nich. To pozdrowienie jest strajkiem wymierzonym w prawo języka, jest gestem niedorzecznym i nielegalnym. Freud przedstawia to hasło jako absurd - cały sen omawia wśród „absurdalnych marzeń sennych” - by następnie obwieścić, że absurd ten był tylko pozorny, można go bowiem rozwikłać: „marzenie senne najczęściej wtedy ma najgłębszy sens, gdy wydaje się z gruntu szalone”, pisze, zakończywszy analizę tego snu ${ }^{34}$. Owszem, nie dlatego jednak, że udaje się rozwikłać kłąb myśli - tego uczynić nie sposób - lecz dlatego, że udaje się dostrzec w nim punkt zbawiennej nierozstrzygalności. Oto bowiem właśnie w tym aporetycznym, bezwyjściowym punkcie, zawieszającym prawo języka i jego normalne funkcjonowanie, blokującym sensowne ścieżki i przejścia, sen Freuda znajduje należyte Wyjście. Albowiem to właśnie w miejscu oznaczonym przez to absurdalne zawołanie pierworodny syn Freuda żegna się z nim i wyrusza w drogę powrotną ku czemuś, czego nigdy nie miał - ku światu poza Prawem - tym samym zaś, na chwilę, w punkcie tego najdziwniejszego imienia-jako-pępka-snu, który zjawia się w konstelacji wszystkich tych faktów, szczegółów i skojarzeń, zmierzając ku szczęściu - uszczęśliwia też swojego ojca. 


\section{Abstract}

\section{Adam Lipszyc}

INSTITUTE OF PHILOSOPHY AND SOCIOLOGY OFTHE POLISH ACADEMY OF SCIENCES

The Name as the Navel of the Dream, or: How to Retrieve the Things We Never Had

This article aims to tie together two distinct models: Freud's method of interpreting dreams and Benjamin's theory of the constellation. By combining these two theoretical constructs we are able to avoid some of the simplifications in Freud's initial model, while also enriching Benjamin's model with a libidinal dimension. An additional dimension in this new concept is provided by Jean Laplanche's interpretation of Freud's writings on the birth of the sex drive. The article closes with an analysis, based on the concept proposed here, of a dream from The Interpretation of Dreams.

\section{Keywords}

Sigmund Freud, Walter Benjamin, dream, constellation, happiness 